Mills, S.W. (2000) Recognizing Middle School Students' Tastes for Popular Music. General Music Today, $13(3)$ : 3. (Spring 2000) Published by Sage (ISSN: 1931-3756).

\title{
Recognizing Middle School Students' Taste for Popular Music
}

\author{
Susan Wilson Mills
}

What happens when your middle school students ask the question, "When can we study our music?" You may cringe, realizing that your efforts to broaden students' musical taste don't necessarily bridge the gap between what they hear outside of school and what you expect them to listen to in school. You carefully consider musical content, age appropriateness, lesson objectives, and accessibility when selecting music for study. What about student-initiated selections? Can we connect music education's desired outcomes and the musical selections with which students may be comfortable?

The need for relevance in education is critical to maintaining students' interest and having them see the connections between the world of school and the "real" world that they experience daily. This interest and the aesthetic enjoyment of hearing a favorite selection in class may increase the time and effort a student is willing to invest in order to truly understand music. Yet students often feel as if there are two kinds of music: the world of classroom music (folk songs, choral anthems, concert band overtures, marches, and so on) and the world of music outside the classroom (television, video, and radio music) (Stuessy, 1994). Elliot Eisner, an advocate of educating for understanding who often writes about meaningful learning, reminds us that the wisdom of a music teacher in connecting salient experiences with concepts and goals will pay off in the classroom (1993). 


\section{RECOGNIZE STUDENTS AS MUSICIANS}

When music that seems irrelevant to students is presented as course content, they may infer that they are incapable of being musicians themselves. After all, if their tastes don't meet their teachers' high expectations, how can students' opinions possibly be valid? Dangerous messages can come across when the only acceptable styles or selections for study are those chosen strictly by the teacher. Students are young musicians and they, like their teachers, bring their prior experiences and their musical preferences with them when they come to music class. Giving them a chance to share these preferences can pay off by encouraging more open conversation about musical content, generating their enthusiasm for the joy of music learning, and providing a backdrop for meaningful listening and evaluating experiences.

Awareness of students' needs is only part of the task of providing music learning activities based on salient experiences. The remainder of the task is to find ways in which students can discover musical concepts and meet learning goals. One way to encourage music students to flourish is by helping them achieve a good working vocabulary of musical terms. When students understand the meaning and usage of musical terms, they build a repertoire of tools for listening and evaluating that can be applied in their personal music preferences outside the classroom. These musical terms can include the traditional Italian words used to denote dynamics in musical scores ("piano," "cantabile," "a capella"), English words used to describe musical form ("bridge," "verse," "lead break"), and words used in composing and analyzing music (variation, reversion, "motive"). Musical elements (melody, rhythm, harmony) are essential in a working vocabulary for listening to and creating music.

\section{INVITE POPULAR PREFERENCES}

Here is a strategy for building a music vocabulary that is fun, relevant to students' musical tastes, and respectful of their aesthetic capabilities.

* Ask students to bring their favorite CDs to music class. Tell them to select one song from the $\mathrm{CD}$ and bring it to music class a few days in advance of the lesson. Listen to unfamiliar material ahead of time to ensure that the language is suitable for classroom use. Ask the students to be ready to state what they like about the songs they select for class. Students will very likely base their selections on the song's lyrical content, the dance rhythm, or some nonmusical reason such as the popularity of the song or group or the association of the song with an event or movie. As students describe what they like about a song, they also reveal valuable information about their tastes and their proficiency with musical language. Most importantly, the students recognize that they are capable of functioning as music critics. If the music class includes journal or portfolio writing, have students write their comments about their selections as the first entry for this project.

* Organize students into groups of three or four. Since all students may not be willing to share their musical tastes in an academic setting, group the students so that at least one person in each group has brought a CD from home. Those who do not bring a CD will benefit from having the option of selecting recordings, and they will benefit from their peers' choices. Ask each group to select one person's recording to play for the class. Write the song title and the name of the performers on the board so that students can enter the information in their journals with the correct spelling. Add a CD of your own to the list from your personal collection. A good choice is 
a movie soundtrack since students may be familiar with the selection, and there are often several artists, styles, and eras represented.

* Select or ask students for ten or so dynamic markings or terms. Print one each on large 11" $x$ 17" cards. Review the terms with students by showing them the cards and defining the terms. For example, one term could be "crescendo." The card could have the crescendo symbol on one side and the word spelled out on the other side. Categorize the musical vocabulary cards according to the basic elements of music. (Sets of cards can also be purchased from educational supply companies.)

* Tell students that they will be matching the terms on the cards with the music being played. Use your own selection as the first example. Play a song with an obvious crescendo and decrescendo and point them out by holding up the cards at the point in the music when they occur. One example is the song "Shout" from the movie Animal House. When the lyrics say "a little bit softer now, a little bit softer now" and "a little bit louder now, a little bit louder now," the volume levels become noticeably soft and then loud again, matching the singers' words.

Select only one or two corresponding terms for each song. (A few examples are shown in the Sample Songs and Terms sidebar.) If only excerpts from the songs are played in class, more students can contribute recording examples, and the discussion will be better focused if students attend to only one or two concepts per song. Used this way, the song serves as a memory aid for the musical term.

Follow up the listening selection with probing questions. For example, ask: "Which instrument(s) created the crescendo/ decrescendo?" or "Why do you think the performers chose to play the music using crescendo/ decrescendo?"

* Using student-selected examples, continue to play excerpts, find corresponding musical terms, and ask questions that will promote class discussion. On a first listening, students can be directed to listen just for a particular musical element. This will keep them from being overwhelmed and will focus their listening on a specific area, such as the form of the song or the use of a melodic tool such as chromatic movement. As they listen, students will hear and describe items not on the original list, and they may need more vocabulary words. Have some blank cards ready for each group. As students prepare to hear their selections, they can choose musical terms to describe their excerpts with help from their small groups.

* Have students continue to work within their small groups. Each group can make a list of all the musical terms and the corresponding musical examples that it selected. In small groups, students can listen to the remaining group members' musical selections, working through the process of stating what they like about the music, finding an example of musical expression in the music, and associating a musical term with the song to add to the group's list. Students will benefit from initiating the discussions based on their own tastes, and at the same time, musical concepts will be discovered and reviewed. Because students select the material to listen to and evaluate, they are engaging in higher-order thinking processes rather than simply recalling definitions or musical examples. 


\section{ENJOY THE PAYOFFS}

Having developed a working music vocabulary enables students to refer to their lists and use the terms as tools for inspiration or description when composing music or creating improvisations in class. The terms, a concrete example of each, and a useful experience with the terms as tools will be assimilated into their working musical vocabulary. The teacher can help students organize their written information by referring to the elements of music from which the student-found concepts are derived. In addition to learning and reviewing dynamics terms, this strategy is also a way to help students categorize their own musical preferences so that they can name the style of music they prefer or have an interest in investigating. Cards with words taken from the categories of recordings at music stores, such as "rap," "gospel," "rhythm \& blues," "ska," "swing," "hardcore," and "grunge," could be used to discuss the elements in the recorded music that place the song or performing group in a particular category of music.

Many educators have demonstrated success in achieving classroom learning objectives by encouraging or even requiring students to take a active role in choosing their learning materials. When students are part of the ongoing learning process, they view development of musical ideas as a very real and important experience (Wiggins, 1995). If students feel a particular kinship with a song or style of music, they are more likely to explore musical possibilities and more likely to challenge themselves because they are comfortable with the sounds in the musical environment.

A serendipitous result of encouraging student choice is that students' musical interests may actually broaden. Eisner (1997) quotes Ernst Gombrich, an art historian, who said, "Artists don't paint what they can see; they see what they can paint" (349). People look for what they know how to find, and what they know how to find is usually related to what they know how to do. If students using a working vocabulary as a foundation learn how to find musical meaning in their own listening experiences, they will begin looking for musical meaning in a more diverse repertoire. Furthermore, students' enjoyment of music is promoted by deliberately making their tastes in music the starting point of the lesson.

A final note: Be prepared for your students to get a laugh out of the CDs that their "old" music teacher uses as examples. What seems like "oldies" to a twelve-year-old may shock you. In addition, be ready for the lively discussion and enthusiasm your students will enjoy as they become more comfortable with and less alienated from musical terms and music learning. 
Sample Songs and Terms

\begin{tabular}{|c|c|c|}
\hline Song and Artist & $C D$ & Musical Term \\
\hline $\begin{array}{l}\text { "Shout" } \\
\text { Elmer Bernstein }\end{array}$ & $\begin{array}{l}\text { Animal House: } \\
\text { The Soundtrack (Uni) }\end{array}$ & $\begin{array}{l}\text { Crescendo/ } \\
\text { decrescendo }\end{array}$ \\
\hline $\begin{array}{l}\text { "One Mint Julep" } \\
\text { Ray Charles }\end{array}$ & $\begin{array}{l}\text { Ray Charles Greatest Hits } \\
\text { (DCC Compact Classics) }\end{array}$ & Portamento \\
\hline $\begin{array}{l}\text { "You Were Meant } \\
\text { for Me" Jewel }\end{array}$ & Pieces of You (Atlantic) & $\begin{array}{l}\text { Deceptive } \\
\text { cadence }\end{array}$ \\
\hline $\begin{array}{l}\text { "Shelter from } \\
\text { the Storm" Bob Dylan }\end{array}$ & $\begin{array}{l}\text { Jerry Maguire: } \\
\text { Music from the } \\
\text { Motion Picture Soundtrack } \\
\text { (Epic Soundtrax) }\end{array}$ & Strophic \\
\hline $\begin{array}{l}\text { "Don't Get Around } \\
\text { Much Anymore" } \\
\text { Harry Connick Jr. }\end{array}$ & $\begin{array}{l}\text { Music From the } \\
\text { Motion Picture } \\
\text { When Harry Met Sally } \\
\text { (Columbia) }\end{array}$ & Chromatic \\
\hline $\begin{array}{l}\text { "Orinoco Flow" } \\
\text { Enya }\end{array}$ & $\begin{array}{l}\text { Watermark } \\
\text { (Wea) }\end{array}$ & Pizzicato \\
\hline $\begin{array}{l}\text { "Vamuvamba" } \\
\text { Mungano National Choir } \\
\text { Kenya }\end{array}$ & $\begin{array}{l}\text { Missa Luba: } \\
\text { An African Mass \& } \\
10 \text { Kenyan Folk Melodies } \\
\text { (Philips Classic) }\end{array}$ & $\begin{array}{l}\text { A cappella, } \\
\text { acoustic }\end{array}$ \\
\hline $\begin{array}{l}\text { "Let It Be" } \\
\text { Tito Nieves with } \\
\text { Tito Puente }\end{array}$ & $\begin{array}{l}\text { Tropical Tribute } \\
\text { to the Beatles } \\
\text { (Uni/RMM) Records }\end{array}$ & Syncopation \\
\hline Song and Artist & $C D$ & Element of Music \\
\hline $\begin{array}{l}\text { "Shout" } \\
\text { Elmer Bernstein }\end{array}$ & $\begin{array}{l}\text { Animal House: } \\
\text { The Soundtrack (Uni) }\end{array}$ & Expression \\
\hline $\begin{array}{l}\text { "One Mint Julep" } \\
\text { Ray Charles }\end{array}$ & $\begin{array}{l}\text { Ray Charles Greatest Hits } \\
\text { (DCC Compact Classics) }\end{array}$ & Expression \\
\hline $\begin{array}{l}\text { "You Were Meant } \\
\text { for Me" Jewel }\end{array}$ & Pieces of You (Atlantic) & Harmony \\
\hline $\begin{array}{l}\text { "Shelter from } \\
\text { the Storm" Bob Dylan }\end{array}$ & $\begin{array}{l}\text { Jerry Maguire: } \\
\text { Music from the } \\
\text { Motion Picture Soundtrack } \\
\text { (Epic Soundtrax) }\end{array}$ & Form \\
\hline $\begin{array}{l}\text { "Don't Get Around } \\
\text { Much Anymore" } \\
\text { Harry Connick Jr. }\end{array}$ & $\begin{array}{l}\text { Music From the } \\
\text { Motion Picture } \\
\text { When Harry Met Sally } \\
\text { (Columbia) }\end{array}$ & Melody \\
\hline
\end{tabular}




\begin{tabular}{|c|c|c|}
\hline $\begin{array}{l}\text { "Orinoco Flow" } \\
\text { Enya }\end{array}$ & $\begin{array}{l}\text { Watermark } \\
\text { (Wea) }\end{array}$ & Expression \\
\hline "Vamuvamba" & Missa Luba: & Tone color \\
\hline Mungano National & An African Mass \& & \\
\hline Choir Kenya & $\begin{array}{l}10 \text { Kenyan Folk Melodies } \\
\text { (Philips Classic) }\end{array}$ & \\
\hline "Let It Be" & Tropical Tribute & Rhythm \\
\hline Tito Nieves with & to the Beatles & \\
\hline Tito Puente & (Uni/RMM) Records & \\
\hline
\end{tabular}

\section{LITERATURE CITED}

Eisner, E. W. 1993. Forms of understanding and the future of educational research. Educational Researcher 22 (7): 5-11.

Eisner, E. W. 1997. Cognition and representation: A way to pursue the American dream. Phi Delta Kappan 78 (5): 348-53.

Stuessy, J. 1994. When the music teacher meets Metallica. Music Educators Journal 79 (4): 2832.

Wiggins, J. 1995. Learning through creative interaction with music. General Music Today 8 (3): 11-15.

Susan Wilson Mills is visiting assistant professor in the College of Education at the University of Central Florida in Orlando. 